\title{
Evaluation of superparamagnetic iron oxide-polymer composite microcapsules for magnetic resonance-guided high-intensity focused ultrasound cancer surgery
}

Yang Sun ${ }^{1}$, Yuanyi Zheng ${ }^{1 *}$, Pan Li', Dong Wang ${ }^{1}$, Chengcheng Niu', Yuping Gong ${ }^{1}$, Rongzhong Huang ${ }^{1}$, Zhibiao Wang ${ }^{2}$, Zhigang Wang ${ }^{1}$ and Haitao Ran ${ }^{1 *}$

\begin{abstract}
Background: Superparamagnetic poly (lactic-co-glycolic acid) (PLGA)-coated $\mathrm{Fe}_{3} \mathrm{O}_{4}$ microcapsules are receiving increased attention as potential diagnostic and therapeutic modalities in the field of oncology. In this study, PLGA-coated $\mathrm{Fe}_{3} \mathrm{O}_{4}$ microcapsules were combined with a magnetic resonance imaging-guided high-intensity focused ultrasound (MR-guided HIFU) platform, with the objective of investigating the effects of these composite microcapsules regarding MR-guided HIFU liver cancer surgery in vivo.

Methods: PLGA-coated $\mathrm{Fe}_{3} \mathrm{O}_{4}$ microcapsules consisting of a liquid core and a PLGA-Fe $\mathrm{O}_{4}$ shell were fabricated using a modified double emulsion evaporation method. Their acute biosafety was confirmed in vitro using MDA cells and in vivo using rabbits. To perform MR-guided HIFU surgery, the microcapsules were intravenously injected into a rabbit liver tumor model before MR-guided HIFU. $T_{2}$-weighted images and MR signal intensity in normal liver parenchyma and tumor tissue were acquired before and after injection, to assess the MR imaging ability of the microcapsules. After MR-guided HIFU ablation tissue temperature mapping, the coagulative volume and histopathology of the tumor tissue were analyzed to investigate the ablation effects of MR-guided HIFUs.

Results: Scanning and transmission electron microscopy showed that the microcapsules displayed a spherical morphology and a shell-core structure (mean diameter, $587 \mathrm{~nm}$ ). The hysteresis curve displayed the typical superparamagnetic properties of the microcapsules, which are critical to their application in MR-guided HIFU surgery. In MR-guided HIFU surgery, these microcapsules functioned as an MRI contrast agent, induced significant hyperthermal enhancement $(P<0.05)$ and significantly enhanced the volume of coagulative necrosis $(P<0.05)$.

Conclusions: The administration of $\mathrm{PLGA}$-coated $\mathrm{Fe}_{3} \mathrm{O}_{4}$ microcapsules is a potentially synergistic technique regarding the enhancement of MR-guided HIFU cancer surgery.
\end{abstract}

Keywords: Cancer surgery, Hyperthermia, HIFU, MRI guidance, Iron oxide, Polymer

\section{Background}

The clinical application of ultrasound is no longer limited to diagnosis. High-intensity focused ultrasound (HIFU) is a newly developed technique that applies ultrasonic energy to a focused region for the hyperthermal treatment of solid tumors [1,2]. Compared with conventional surgical,

\footnotetext{
*Correspondence: zhengyuanyi@gmail.com; ranhaitao66@gmail.com 'Second Affiliated Hospital, Institute of Ultrasound Imaging, Chongqing Medical University, Chongqing, P. R. China

Full list of author information is available at the end of the article
}

chemotherapeutic and radiotherapeutic approaches, HIFU is a logical and attractive treatment modality that can selectively and non-invasively destroy multiple foci of origin $[3,4]$. Moreover, HIFU provides additional therapeutic options in cases where conventional therapies have failed [5-7].

HIFU performance critically relies on imaging quality for an accurate determination of tumor location to facilitate the optimal deposition of ultrasonic energy in the tumor. The integration of magnetic resonance imaging

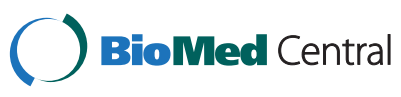

(C) 2014 Sun et al.; licensee BioMed Central Ltd. This is an Open Access article distributed under the terms of the Creative Commons Attribution License (http://creativecommons.org/licenses/by/4.0), which permits unrestricted use, distribution, and reproduction in any medium, provided the original work is properly credited. The Creative Commons Public Domain Dedication waiver (http://creativecommons.org/publicdomain/zero/1.0/) applies to the data made available in this article, unless otherwise stated. 
(MRI) and HIFU forms an MR-guided HIFU system that offers superior soft tissue MRI resolution combined with non-invasive real-time tissue temperature mapping ( $\mathrm{T}$ Map) capabilities [8-10]. Consequently, MR-guided HIFU is being increasingly used in the clinic [11-14]. Despite its growing clinical acceptance, MR-guided HIFU has two key limitations. First, MRI as used in MR-guided HIFU can fail to visualize small early stage or MRI-insensitive tumors [15-17]. Second, the ultrasonic energy emitted by the MRguided HIFU transducer is considerably attenuated when shifting from an in vitro environment to in vivo tissue; this attenuation adversely affects MR-guided HIFU ablation efficiency because the ability of HIFU to successfully ablate tumors depends on its capacity to deposit energy in tissue [18-21]. Therefore, limitations in tumor visualization and in vivo energy deposition adversely affect the treatment efficacy of MR-guided HIFU.

Superparamagnetic iron-oxide nanoparticles (SPIONs) possess unique magnetic properties that make them attractive advanced biomaterial candidates [22-25]. In cancer diagnosis and therapy, SPIONs can serve as MRI contrast agents [26,27], miniaturized heaters capable of destroying malignant cells and colloidal carriers for targeted drug delivery [28-30]. Since SPION-enhanced MR imaging can be used to monitor the tumor prior to ablation therapy, SPIONs are particularly suitable for MRguided HIFU applications. Moreover, as a functional medium, SPIONs can also change the acoustic tissue microenvironment in the targeted region, thereby enhancing the tumor-ablative effects of MR-guided HIFUs.

The objective of the present study was to combine the merits of SPIONs and polymers by constructing a composite particle, namely the superparamagnetic poly (lactic-co-glycolic acid) (PLGA)-coated $\mathrm{Fe}_{3} \mathrm{O}_{4}$ microcapsule. We investigated the in vitro properties of these superparamagnetic PLGA-coated $\mathrm{Fe}_{3} \mathrm{O}_{4}$ microcapsules and the in vivo application of these microcapsules in MRguided HIFU liver cancer surgery using a rabbit model.

\section{Methods}

\section{Synthesis of PLGA-coated $\mathrm{Fe}_{3} \mathrm{O}_{4}$ microcapsules}

Preparation and storage of the microcapsules were performed in the dark. Briefly, a $200-\mathrm{ml}$ solution $(3.1 \% \mathrm{w} / \mathrm{v})$ of nano-sized $\mathrm{Fe}_{3} \mathrm{O}_{4}$ particles $(31 \mathrm{mg} / \mathrm{ml}$; size, $10 \mathrm{~nm}$; Ocean NanoTech, USA) was added to $2 \mathrm{ml}$ of $\mathrm{CH}_{3} \mathrm{Cl}$ dissolved in $100 \mathrm{mg}$ of PLGA (50:50; $\mathrm{MW}=20000$; Daigang, China). For cell incubation, the fluorescent dye DiI was incorporated into the composite microcapsules. The above mixture was emulsified (Sonics \& Materials Inc., USA) for $45 \mathrm{~s}$. After adding $200 \mathrm{ml}$ of deionized water, the solution was homogenized (FJ300-SH, Shanghai, China) for $5 \mathrm{~min}$ with a $10-\mathrm{ml}$ poly(vinyl alcohol) (PVA; MW = 25000; Sigma) solution (5\% w/v). Then, the $\mathrm{CH}_{3} \mathrm{Cl}$ solution was removed by mechanical mixing for
$2 \mathrm{~h}$. The mixture was subsequently centrifuged at $800 \mathrm{rpm}$ for $10 \mathrm{~min}$. After centrifugation, the precipitate containing large microcapsules was discarded, and the functionalized PLGA-coated $\mathrm{Fe}_{3} \mathrm{O}_{4}$ microcapsules were generated by a second centrifugation of the remaining microcapsule suspension at $5000 \mathrm{rpm}$ for $5 \mathrm{~min}$. In addition, pure PLGA microcapsules were prepared without the addition of $\mathrm{Fe}_{3} \mathrm{O}_{4}$ particles and used as a control agent.

\section{Characterizing PLGA-coated $\mathrm{Fe}_{3} \mathrm{O}_{4}$ microcapsules}

The average size of the PLGA-coated $\mathrm{Fe}_{3} \mathrm{O}_{4}$ microcapsules was characterized using the Laser Particle Size Analyzer System (Zeta SIZER 3000HS: Malvern, PA, USA). The morphological and structural characteristics of the microcapsules were estimated using scanning electron microscopy (SEM) (S-3400 N: Hitachi, Japan) and transmission electron microscopy (TEM) (H-7500: Hitachi, Japan). DiI-labeled PLGA microcapsules were observed using inverted fluorescence microscopy (Olympus IX71: Canada). The magnetic properties of the microcapsules were investigated using the Physical Property Measurement System (PPMS, Model 6000: Quantum Design).

\section{MDA cell culture and PLGA-coated $\mathrm{Fe}_{3} \mathrm{O}_{4}$ microcapsule uptake by MDA cells}

MDA cells obtained from the American Type Culture Collection (ATCC, USA) were cultured in RPMI-1640 medium supplemented with 10\% FBS (both from Hycline) at $37^{\circ} \mathrm{C}$ with $5 \% \mathrm{CO}_{2}$ in a humidified atmosphere and passaged every 2-3 days. DiI-labeled PLGAcoated $\mathrm{Fe}_{3} \mathrm{O}_{4}$ microcapsules were irradiated using a $\mathrm{Co}^{60}$ gamma ray source for sterilization prior to incubation with MDA cells.

MDA cells $\left(2 \times 10^{5}\right.$ per well $)$ were placed on six-well tissue-culture clusters $24 \mathrm{~h}$ before incubation with PLGA-coated $\mathrm{Fe}_{3} \mathrm{O}_{4}$ microcapsules. Immediately before initiating incubation, the medium was removed from each well and the cells were washed three times with PBS. They were then incubated with the DiI-labeled PLGA-coated $\mathrm{Fe}_{3} \mathrm{O}_{4}$ microcapsules as described below. The microcapsules were diluted to a final $\mathrm{Fe}_{3} \mathrm{O}_{4}$ concentration of $0.15 \mathrm{mg} / \mathrm{ml}$ with culture medium and subsequently added to each well. Cells in culture medium without agents were used as the control group. The cells with PLGA-coated $\mathrm{Fe}_{3} \mathrm{O}_{4}$ were individually cultured for 4, 12 and $24 \mathrm{~h}$, while the control group was cultured for $24 \mathrm{~h}$. Thereafter, the medium was removed from each well, and the cells were washed three times with PBS and fixed in $10 \%$ formalin solution for $10 \mathrm{~min}$. The cells were then stained using FITC for $45 \mathrm{~min}$ and Hoechst for $30 \mathrm{~min}$ before observation under an inverted fluorescence microscope. 


\section{MTT assay}

Cell viability was determined using the MTT test. MDA cells $\left(1 \times 10^{4}\right.$ per well) were seeded into 96 -well plates. After incubation for $24 \mathrm{~h}$, the medium was removed and replaced with fresh culture medium containing PLGAcoated $\mathrm{Fe}_{3} \mathrm{O}_{4}$ microcapsules at $\mathrm{Fe}_{3} \mathrm{O}_{4}$ concentrations of $0.5,1.0,2.0,4.0$ and $8.0 \mathrm{mg} / \mathrm{ml}$. Cells in culture medium without agents were used as the control group. Following $24 \mathrm{~h}$ incubation, cell viability was measured by the addition of $20 \mu \mathrm{l}$ 3-(4,5-dimethylthiazol-2-yl)-2, 5diphenyltetrazolium bromide (MTT; $5 \mathrm{mg} / \mathrm{ml}$ ) solution for $4 \mathrm{~h}$. Then, $150 \mu \mathrm{l}$ of DMSO was added to dissolve the formazan crystals. To assess cell viability, optical density (OD) was measured at $490 \mathrm{~nm}$ with an enzymelinked immunosorbent assay (ELISA) plate reader.

\section{Acute biosafety of PLGA-coated $\mathrm{Fe}_{3} \mathrm{O}_{4}$ microcapsules}

Thirty-six New Zealand white rabbits (weight, 2.0$2.5 \mathrm{~kg}$; age, 2-3 months) were purchased and maintained in the Animal Center of Chongqing Medical University under standard conditions in accordance with the university's environmental guidelines. All animal experiments were approved by the Animal Ethics Committee of Chongqing Medical University. All animal experiments and procedures were performed under complete anesthesia.

Prior to tumor implantation, 18 rabbits were divided into three groups to determine a safe dosage of PLGAcoated $\mathrm{Fe}_{3} \mathrm{O}_{4}$ microcapsules. Each group received a 2-ml injection of a different concentration of PLGA-coated $\mathrm{Fe}_{3} \mathrm{O}_{4}$ microcapsules via the ear vein, at $\mathrm{Fe}_{3} \mathrm{O}_{4}$ concentrations of 1,4 and $8 \mathrm{mg} / \mathrm{ml}$. Serum was sampled from the rabbits to detect biochemical indicators of liver, kidney and cardiac function before injection and at 1, 3 and 7 days after injection of the PLGA-coated $\mathrm{Fe}_{3} \mathrm{O}_{4}$ microcapsules. These biochemical indicators included alanine aminotransferase (ALT), aspartate aminotransferase (AST), total bilirubin (TBIL), blood urea nitrogen (BUN), creatinine $(\mathrm{SCr})$, creatine kinase $(\mathrm{CK})$ and lactate dehydrogenase (LDH).

\section{Animal model and experimental equipment}

Rabbits with a VX2 tumor located in the thigh were obtained from the Ultrasound Engineering Institute of Chongqing Medical University (Chongqing Medical University). The liver tumor model was developed according to a previously described method [31].

The 18 recipient rabbits with detectable liver cancer (21 days after VX2 tumor implantation) underwent MRguided HIFU treatment using Symphony A Tim $1.5 \mathrm{~T}$ MR-guided HIFU tumor ablation equipment (therapeutic transducer focal length, $145 \mathrm{~mm}$; diameter, $220 \mathrm{~mm}$; operating frequency, $0.94 \mathrm{MHz}$; Chongqing Haifu Technology, Chongqing, China). This system uses a focused ultrasonic transducer that emits high-intensity ultrasonic energy to target and destroy the tissue-ofinterest, while the diagnostic MR scanner images the tumor and monitors the targeted tissue temperature during the therapeutic process.

\section{MR-guided HIFU surgery for rabbits bearing the VX2 liver tumor}

The 18 recipient rabbits with VX2 liver tumors were placed on the MR-guided HIFU treatment bed in the prone position after being completely anesthetized. Their abdomens were entirely immersed in degassed water. The rabbits were randomly divided into three groups: (i) MR-guided HIFU treatment without microcapsules (group I; $\mathrm{n}=6$ ); (ii) MR-guided HIFU treatment with a 2-ml intravenous injection of pure PLGA microcapsules at a PLGA concentration of $50 \mathrm{mg} / \mathrm{ml}$ (group II; $n=6$ ); and (iii) MR-guided HIFU treatment with a 2$\mathrm{ml}$ intravenous injection of PLGA-coated $\mathrm{Fe}_{3} \mathrm{O}_{4}$ microcapsules at a $\mathrm{Fe}_{3} \mathrm{O}_{4}$ concentration of $3.1 \mathrm{mg} / \mathrm{ml}$ (group III; $\mathrm{n}=6$ ). Prior to MR-guided HIFU ablation, $\mathrm{T}_{2-}$ weighted images were acquired before and at 5 min after ear vein injection of pure PLGA microcapsules (group II) and PLGA-coated $\mathrm{Fe}_{3} \mathrm{O}_{4}$ microcapsules (group III). No injection of microcapsules was administered to rabbits in group I; thus, in group I, the second image was acquired at $5 \mathrm{~min}$ after the acquisition of the first image. Additionally, the MR signal intensity (SI) within the region of interest (including both normal liver parenchyma and liver tumor) was measured before and at 2 and 5 min after injection of the various agents to assess the enhanced MR imaging ability. After MR scanning, MR-guided HIFU ablation was performed using the "ablated-dot" mode, in which each tumor was destroyed in a single exposure. In all three MR-guided HIFU groups (groups I, II and III), MR-guided HIFU ablation parameters were kept constant with a $250-\mathrm{W}$ acoustic power and a 5-s exposure duration. During MR-guided HIFU ablation, T-Map was imaged in the targeted region to investigate the effects of MR-guided HIFU ablation. To acquire $\mathrm{T}_{2}$-weighted images, turbo spin echo (TSE) sequences were run at TR values of $4100 \mathrm{~ms}$ (TE, $113 \mathrm{~ms}$; FOV, $300 \mathrm{~mm} \times 300 \mathrm{~mm}$; slice thickness, $4.0 \mathrm{~mm}$ ).

Animals were sacrificed after MR-guided HIFU ablation, and the livers were immediately removed for macroscopic observation. The tumor along with the surrounding normal liver tissue was sectioned into 2$\mathrm{mm}$ slices, and the maximal section of necrotic tumor tissue was selected for observation of the area of coagulative necrosis. Then, the length, width and depth of the necrotic tissue were compiled from each tissue slice to calculate the volume of coagulative necrosis. The volume of coagulated tissues in the liver tumor was 

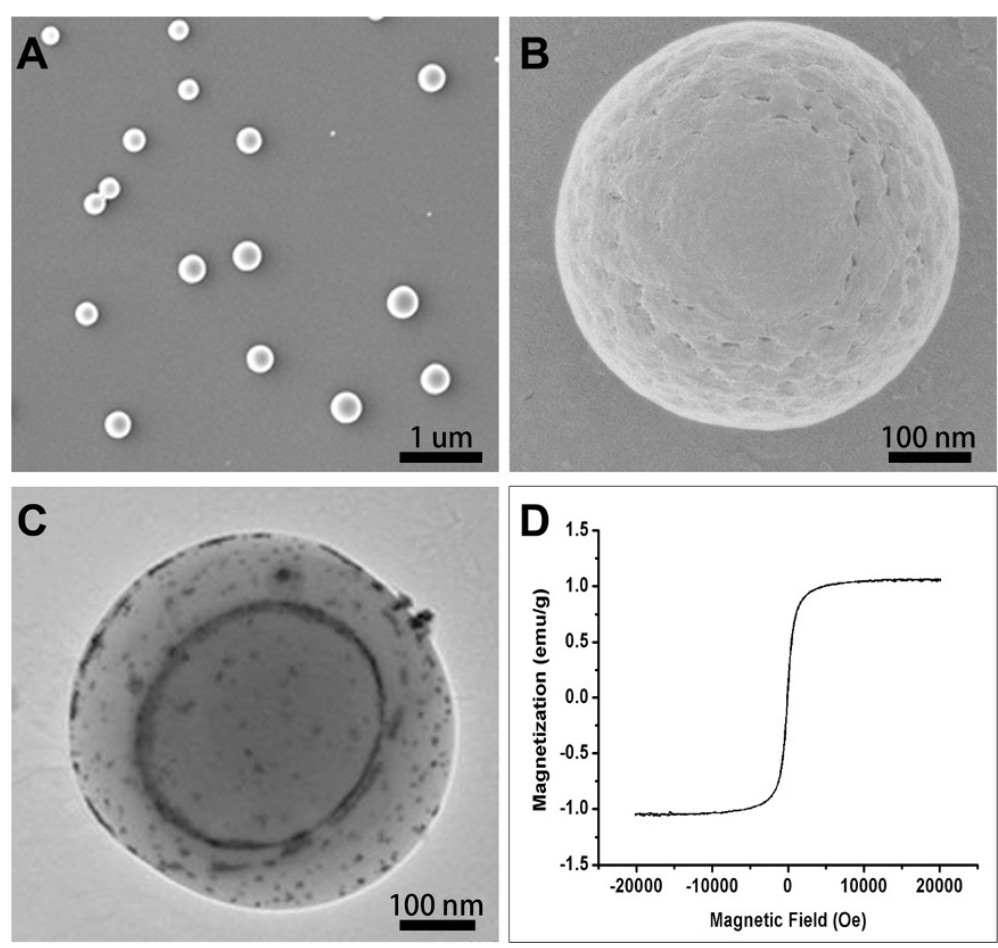

Figure 1 The characterization of superparamagnetic PLGA-coated $\mathrm{Fe}_{3} \mathrm{O}_{4}$ microcapsules. (A, B) Scanning electron microscope images of the PLGA-coated $\mathrm{Fe}_{3} \mathrm{O}_{4}$ microcapsules at different magnifications. (C) Transmission electron microscope images of the PLGA-coated Fe $\mathrm{O}_{4}$ microcapsules. (D) Magnetic properties of the superparamagnetic PLGA-coated $\mathrm{Fe}_{3} \mathrm{O}_{4}$ microcapsules (M-H magnetization curve).

calculated using the following equation: $\mathrm{V}=\pi / 6 \times \mathrm{L} \times$ $\mathrm{W} \times \mathrm{D}$ (L, length; W, width; D, depth) [32]. In addition, TEM was performed on the ablated tissue from each tumor to detect ultrastructural changes in the cancerous tissue.

\section{Statistical analysis}

All data are expressed as the mean \pm standard deviation. Various groups were compared for differences using one-way analysis of variance (one-way ANOVA). All analyses were performed using SPSS Statistics 19.0. A difference with a $P$-value of $<0.05$ was deemed statistically significant.

\section{Results and discussion}

Characterization of PLGA-coated $\mathrm{Fe}_{3} \mathrm{O}_{4}$ microcapsules

According to the microcapsule size distribution (Additional file 1), the mean diameter of the prepared PLGA-coated $\mathrm{Fe}_{3} \mathrm{O}_{4}$ microcapsules was $587 \pm 60 \mathrm{~nm}$. The characteristic pore cutoff size ranged from 380 to $780 \mathrm{~nm}$ and has

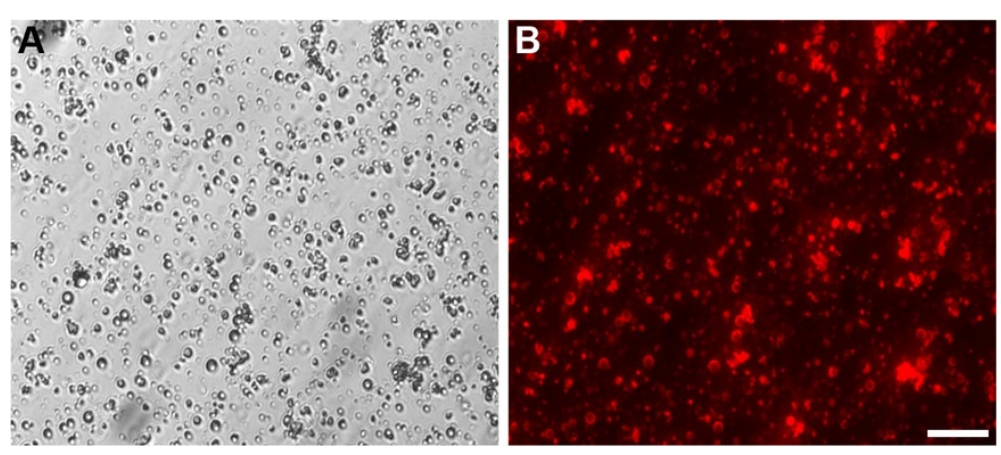

Figure 2 Morphology of Dil-labeled PLGA-coated $\mathrm{Fe}_{3} \mathrm{O}_{4}$ microcapsules. (A) Appearance of microcapsules under light microscopy. (B) Appearance of microcapsules under fluorescence microscopy. Scale bar: $10 \mu \mathrm{m}$. 


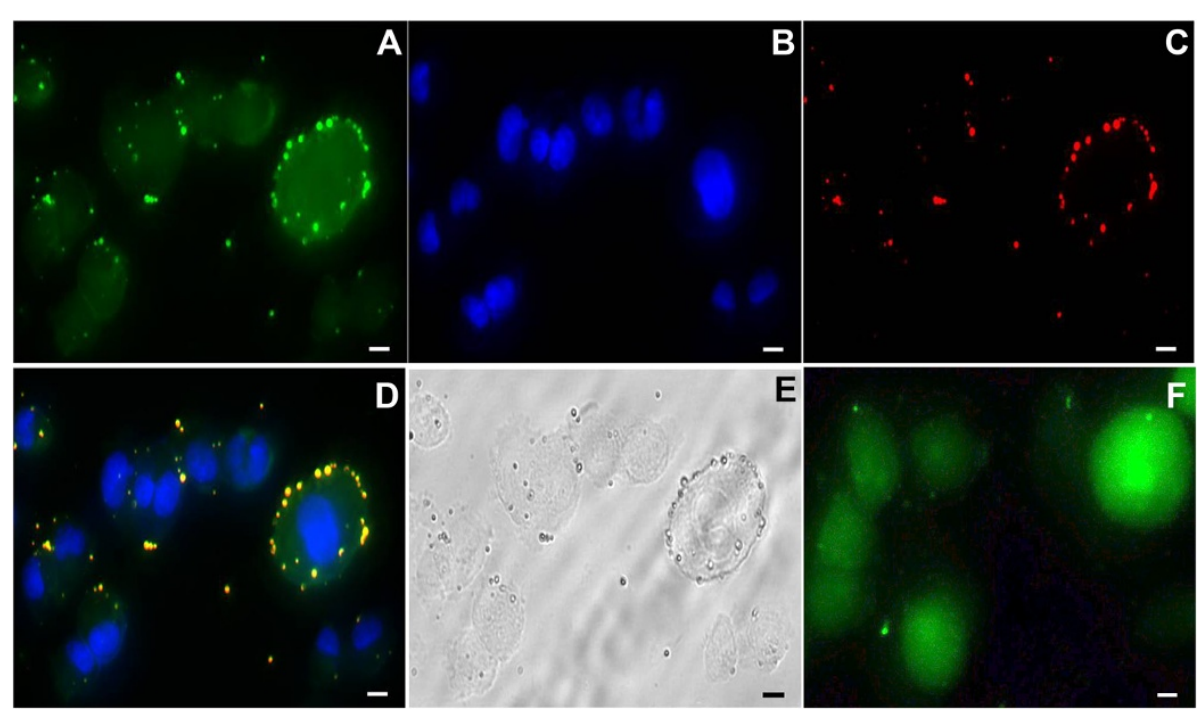

Figure 3 Uptake of PLGA-coated $\mathrm{Fe}_{3} \mathrm{O}_{4}$ microcapsules by MDA cells observed under fluorescence microscopy. (A) MDA cells after incubation with Dil-labeled PLGA-coated $\mathrm{Fe}_{3} \mathrm{O}_{4}$ microcapsules for $4 \mathrm{~h}$ followed by FITC staining for $45 \mathrm{~min}$. The cytoplasm appears green. (B) MDA cells after staining with Hoechst for 30 min with the nucleus appearing blue. (C) Dil-labeled PLGA-coated Fe $\mathrm{O}_{4}$ with a red appearance under fluorescence microscopy. (D) Merged images of (A), (B) and (C). (E) Appearance of microcapsules under light microscopy. (F) MDA cells after staining with FITC in the absence of PLGA particles. Scale bar: $10 \mu \mathrm{m}$.

been demonstrated in a variety of tumors, although some tumors show pore sizes of $\leq 2 \mu \mathrm{m}$ [33-35]. In our study, the smallest particles (approximately $10-20 \%$ of the total particles) in the distribution could enter the tumor tissue by means of the enhanced permeability

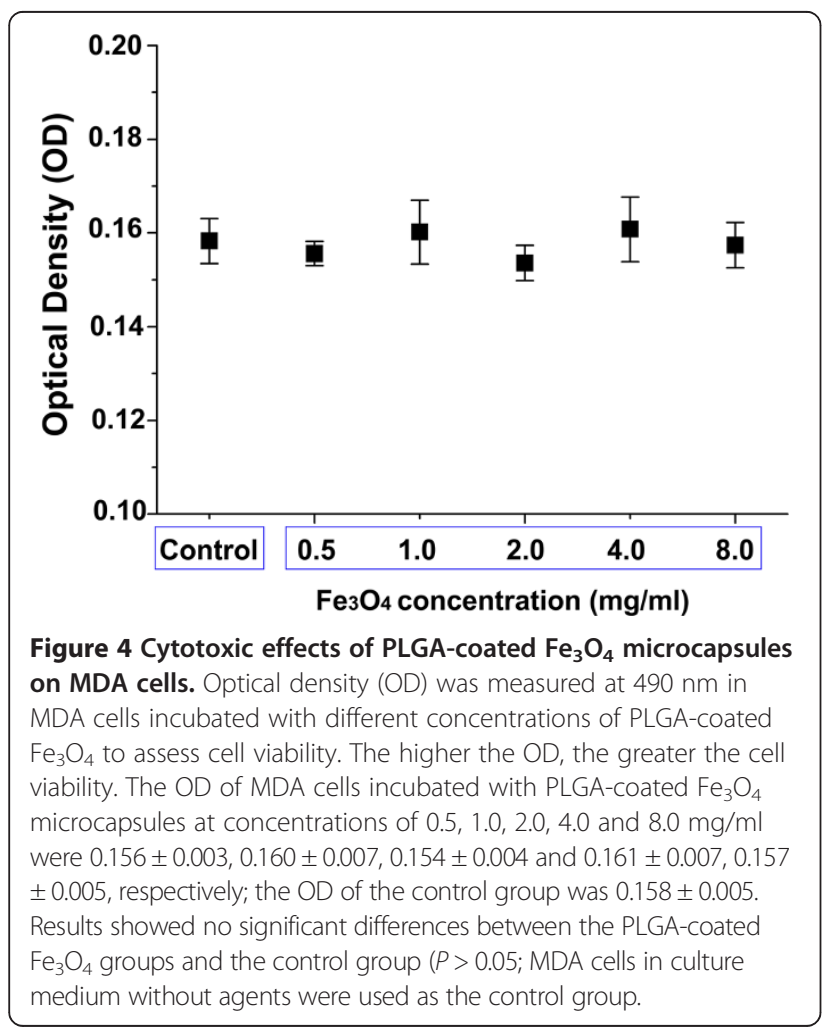

and retention (EPR) effect, which allows extravasation of nanoparticles through large inter-endothelial gaps in the effective tumor microvasculature for the induction of the MR signal and HIFU synergistic therapy.

Under SEM imaging, the prepared microcapsules displayed a spherical morphology and a non-smooth surface (Figure $1 \mathrm{~A}$ and $\mathrm{B}$ ). Because of their organic solubility and small size, the $\mathrm{Fe}_{3} \mathrm{O}_{4}$ nanoparticles embedded themselves in the PLGA shell structure when introduced into the reaction medium prior to the addition of the PVA molecules in the second emulsion. This structure was confirmed by TEM imaging (Figure 1C), where the $\mathrm{Fe}_{3} \mathrm{O}_{4}$ nanoparticles were observed on the surface of the microcapsules as a result of their high electron intensity. The hysteresis curve (Figure 1D) demonstrated the typical superparamagnetic properties of the PLGAcoated $\mathrm{Fe}_{3} \mathrm{O}_{4}$ microcapsules, which are critical to their application in MR-guided HIFU surgery.

DiI is a non-cytotoxic lipophilic orange-red fluorescent dye that does not affect cell growth and proliferation. In the preparation process, DiI was miscible with PLGA and $\mathrm{Fe}_{3} \mathrm{O}_{4}$ in chloroform during the formation of the shell of the composite microcapsules. Using fluorescence microscopy, the surface of the microcapsules displayed the ring-shaped orange-red fluorescent dye DiI (Figure 2).

\section{Uptake of PLGA-coated $\mathrm{Fe}_{3} \mathrm{O}_{4}$ microcapsules by MDA cells}

To observe the cellular uptake of PLGA-coated $\mathrm{Fe}_{3} \mathrm{O}_{4}$ microcapsules, as well as the impact of these microcapsules 
Table 1 Serum biochemical indicators after the injection of PLGA-coated $\mathrm{Fe}_{3} \mathrm{O}_{4}$ microcapsules $(1 \mathrm{mg} / \mathrm{ml})$

\begin{tabular}{lcccc}
\hline & Pre-injection & $\mathbf{1 ~ d}$ & $\mathbf{3 ~ d ~}$ & $\mathbf{7} \mathbf{d}$ \\
\hline ALT $(\mathrm{U} / \mathrm{L})$ & $64.33 \pm 18.34$ & $56.67 \pm 15.01$ & $51.00 \pm 13.89$ & $54.00 \pm 16.09$ \\
AST $(\mathrm{U} / \mathrm{L})$ & $41.33 \pm 1.53$ & $42.33 \pm 2.52$ & $40.67 \pm 4.16$ & $45.33 \pm 2.08$ \\
TBIL $(\mu \mathrm{mol} / \mathrm{L})$ & $3.47 \pm 0.40$ & $3.53 \pm 0.15$ & $3.27 \pm 0.12$ & $3.20 \pm 0.26$ \\
$\mathrm{BUN}(\mathrm{mmol} / \mathrm{L})$ & $7.55 \pm 0.38$ & $8.42 \pm 0.39$ & $7.81 \pm 0.77$ & $7.50 \pm 0.62$ \\
$\mathrm{SCr}(\mu \mathrm{mol} / \mathrm{L})$ & $68.77 \pm 7.60$ & $73.70 \pm 4.40$ & $62.37 \pm 4.10$ & $75.30 \pm 9.04$ \\
CK $(\mathrm{U} / \mathrm{L})$ & $3242.67 \pm 71.14$ & $3420.00 \pm 172.50$ & $3457.67 \pm 132.50$ & $3362.33 \pm 116.11$ \\
LDH $(\mathrm{U} / \mathrm{L})$ & $839.67 \pm 10.02$ & $850.67 \pm 19.86$ & $834.00 \pm 18.00$ & $857.00 \pm 12.77$ \\
\hline
\end{tabular}

Note: The same indicators at different time points for pairwise comparisons ( $P>0.05$ for all of the comparisons).

on cell viability, MDA cells were incubated with DiIlabeled PLGA-coated $\mathrm{Fe}_{3} \mathrm{O}_{4}$ over different periods of time. Fluorescence microscopy demonstrated that PLGA-coated $\mathrm{Fe}_{3} \mathrm{O}_{4}$ microcapsules were phagocytosed by MDA cells (Figure 3), with the number of phagocytosed microcapsules increasing with incubation time (12 and $24 \mathrm{~h}$ ). In Figure 3, MDA cells were stained with FITC and Hoechst for $45 \mathrm{~min}$ and $30 \mathrm{~min}$, respectively, after incubation with DiI-labeled PLGA-coated $\mathrm{Fe}_{3} \mathrm{O}_{4}$ microcapsules for $4 \mathrm{~h}$. After staining, the cytoplasm of the MDA cells appeared green (Figure 3A), the nucleus appeared blue (Figure 3B), and DiI-labeled PLGAcoated $\mathrm{Fe}_{3} \mathrm{O}_{4}$ appeared red (Figure 3C) under fluorescence microscopy. There appear to be green dots in Figure $3 \mathrm{~A}$ in the same place as the dots in Figure $3 \mathrm{C}$. We suspect that these dots were PLGA particles that were stained by FITC; in addition, we could see the merged color in the same location (Figure 3D) but we could not observe these green dots in MDA cells without incubation of the PLGA particles after staining with FITC (Figure 3F). Thus, we believe that FITC has the ability to label PLGA particles.

In addition, the OD of MDA cells incubated with PLGA-coated $\mathrm{Fe}_{3} \mathrm{O}_{4}$ at concentrations of 0.5, 1.0, 2.0, 4.0 and $8.0 \mathrm{mg} / \mathrm{ml}$ were $0.156 \pm 0.003,0.160 \pm 0.007,0.154 \pm$ $0.004,0.161 \pm 0.007$ and $0.157 \pm 0.005$, respectively; the OD of the control group was $0.158 \pm 0.005$. The MTT assay indicated that the phagocytosed microcapsules had no significant effect on cell viability relative to the controls $(P>0.05$; Figure 4).

\section{Acute biosafety of PLGA-coated $\mathrm{Fe}_{3} \mathrm{O}_{4}$ microcapsules}

We injected the PLGA-coated Fe3O4 microcapsules into rabbits to investigate their acute biosafety in vivo. After injection of three different concentrations of the microcapsules $\left(\mathrm{Fe}_{3} \mathrm{O}_{4}\right.$ concentrations of $1 \mathrm{mg} / \mathrm{ml}, 4 \mathrm{mg} / \mathrm{ml}$ and $8 \mathrm{mg} / \mathrm{ml}$ ), there were no obvious abnormalities in all three groups of rabbits. The serum biochemical indicators (Tables 1, 2 and 3) demonstrated that liver, kidney and cardiac function in the three groups showed no significant changes $(P>0.05)$ at the different post-injection time points (1, 3 and 7 days).

\section{PLGA-coated $\mathrm{Fe}_{3} \mathrm{O}_{4}$ microcapsules as contrast agents for MR-guided HIFU surgery}

We then investigated the use of PLGA-coated $\mathrm{Fe}_{3} \mathrm{O}_{4}$ microcapsules as contrast agents in MR-guided HIFU ablation. As shown in the $\mathrm{T}_{2}$-weighted images in Figure 5 $\mathrm{A}_{1,2}, \mathrm{~B}_{1,2}$ and $\mathrm{C}_{1,2}$, PLGA-coated $\mathrm{Fe}_{3} \mathrm{O}_{4}$ microcapsules generated negative contrast enhancement in the liver (Figure $5 \mathrm{C}_{2}$ ). Changes in the MR SI of the liver further demonstrated this effect. As shown in Figure 6, the SIs of liver parenchyma in the control, PLGA-coated $\mathrm{Fe}_{3} \mathrm{O}_{4}$ and PLGA groups before injection, and at 2 and $5 \mathrm{~min}$ after injection were as follows: $928.25 \pm 17.41,908.24 \pm$ 17.38 and $921.04 \pm 15.88$ (pre-injection); $919.54 \pm 18.28$,

Table 2 Serum biochemical indicators after the injection of PLGA-coated $\mathrm{Fe}_{3} \mathrm{O}_{4}$ microcapsules $(4 \mathrm{mg} / \mathrm{ml})$

\begin{tabular}{lcccc}
\hline & Pre-injection & $\mathbf{1 ~ d}$ & $\mathbf{3 ~ d}$ & $\mathbf{7} \mathbf{d}$ \\
\hline ALT $(\mathrm{U} / \mathrm{L})$ & $50.80 \pm 14.23$ & $57.17 \pm 14.06$ & $63.53 \pm 17.35$ & $53.70 \pm 15.11$ \\
AST $(\mathrm{U} / \mathrm{L})$ & $43.33 \pm 1.56$ & $41.35 \pm 2.46$ & $41.63 \pm 3.56$ & $43.83 \pm 2.15$ \\
TBIL $(\mu \mathrm{mol} / \mathrm{L})$ & $3.45 \pm 0.39$ & $3.54 \pm 0.17$ & $3.29 \pm 0.14$ & $3.21 \pm 0.33$ \\
BUN $(\mathrm{mmol} / \mathrm{L})$ & $7.79 \pm 0.67$ & $8.45 \pm 0.37$ & $7.65 \pm 0.48$ & $7.66 \pm 0.58$ \\
$\mathrm{SCr}(\mu \mathrm{mol} / \mathrm{L})$ & $66.57 \pm 6.70$ & $72.73 \pm 4.37$ & $64.26 \pm 4.11$ & $74.80 \pm 8.05$ \\
CK $(\mathrm{U} / \mathrm{L})$ & $3354.39 \pm 96.61$ & $3422.00 \pm 112.53$ & $3446.62 \pm 122.30$ & $3277.65 \pm 69.40$ \\
LDH $(\mathrm{U} / \mathrm{L})$ & $841.67 \pm 11.02$ & $848.63 \pm 17.83$ & $823.14 \pm 16.73$ & $856.37 \pm 13.42$ \\
\hline
\end{tabular}

Note: The same indicators at different time points for pairwise comparisons ( $P>0.05$ for all of the comparisons). 
Table 3 Serum biochemical indicators after the injection of PLGA-coated $\mathrm{Fe}_{3} \mathrm{O}_{4}$ microcapsules $(8 \mathrm{mg} / \mathrm{ml})$

\begin{tabular}{lcccc}
\hline & Pre-injection & $\mathbf{1 ~ d}$ & $\mathbf{3 ~ d}$ & $\mathbf{7} \mathbf{d}$ \\
\hline ALT $(\mathrm{U} / \mathrm{L})$ & $59.23 \pm 13.77$ & $56.15 \pm 14.55$ & $51.30 \pm 13.87$ & $61.23 \pm 16.55$ \\
AST $(\mathrm{U} / \mathrm{L})$ & $42.88 \pm 1.45$ & $41.09 \pm 1.65$ & $41.64 \pm 2.00$ & $43.56 \pm 3.15$ \\
TBIL $(\mu \mathrm{mol} / \mathrm{L})$ & $3.49 \pm 0.38$ & $3.48 \pm 0.23$ & $3.37 \pm 0.34$ & $3.23 \pm 0.32$ \\
BUN $(\mathrm{mmol} / \mathrm{L})$ & $7.58 \pm 0.32$ & $8.44 \pm 0.43$ & $7.76 \pm 0.53$ & $7.59 \pm 0.63$ \\
$\mathrm{SCr}(\mu \mathrm{mol} / \mathrm{L})$ & $69.65 \pm 5.74$ & $71.88 \pm 4.43$ & $66.30 \pm 5.31$ & $75.79 \pm 7.98$ \\
CK $(\mathrm{U} / \mathrm{L})$ & $3280.98 \pm 66.33$ & $3445.09 \pm 98.71$ & $3453.98 \pm 112.27$ & $3325.0 \pm 111.20$ \\
LDH $(\mathrm{U} / \mathrm{L})$ & $853.34 \pm 10.71$ & $847.72 \pm 15.30$ & $838.99 \pm 17.90$ & $850.08 \pm 16.98$ \\
\hline
\end{tabular}

Note: The same indicators at different time points for pairwise comparisons ( $P>0.05$ for all of the comparisons).

$137.65 \pm 15.23$ and $938.39 \pm 16.45(2 \mathrm{~min})$; and $925.59 \pm$ 16.27, $271.34 \pm 15.97$ and $917.58 \pm 16.47$ (5 min), respectively. In addition, the SIs of liver tumors in the control, PLGA-coated $\mathrm{Fe}_{3} \mathrm{O}_{4}$ and PLGA groups before injection and at 2 and $5 \mathrm{~min}$ after injection were as follows: $921.37 \pm 17.91,918.76 \pm 16.88$ and $913.64 \pm 15.88$ (pre-injection); $924.65 \pm 18.28,783.64 \pm 12.53$ and $906.25 \pm$ 16.45 (2 $\mathrm{min}) ;$ and 922.44 $\pm 18.37,761.53 \pm 13.57$ and $908.52 \pm 14.57$ (5 min), respectively. The differences in the results were analyzed statistically between the groups and between the time points. Although there were no significant changes in SI after the injection of pure PLGA or no

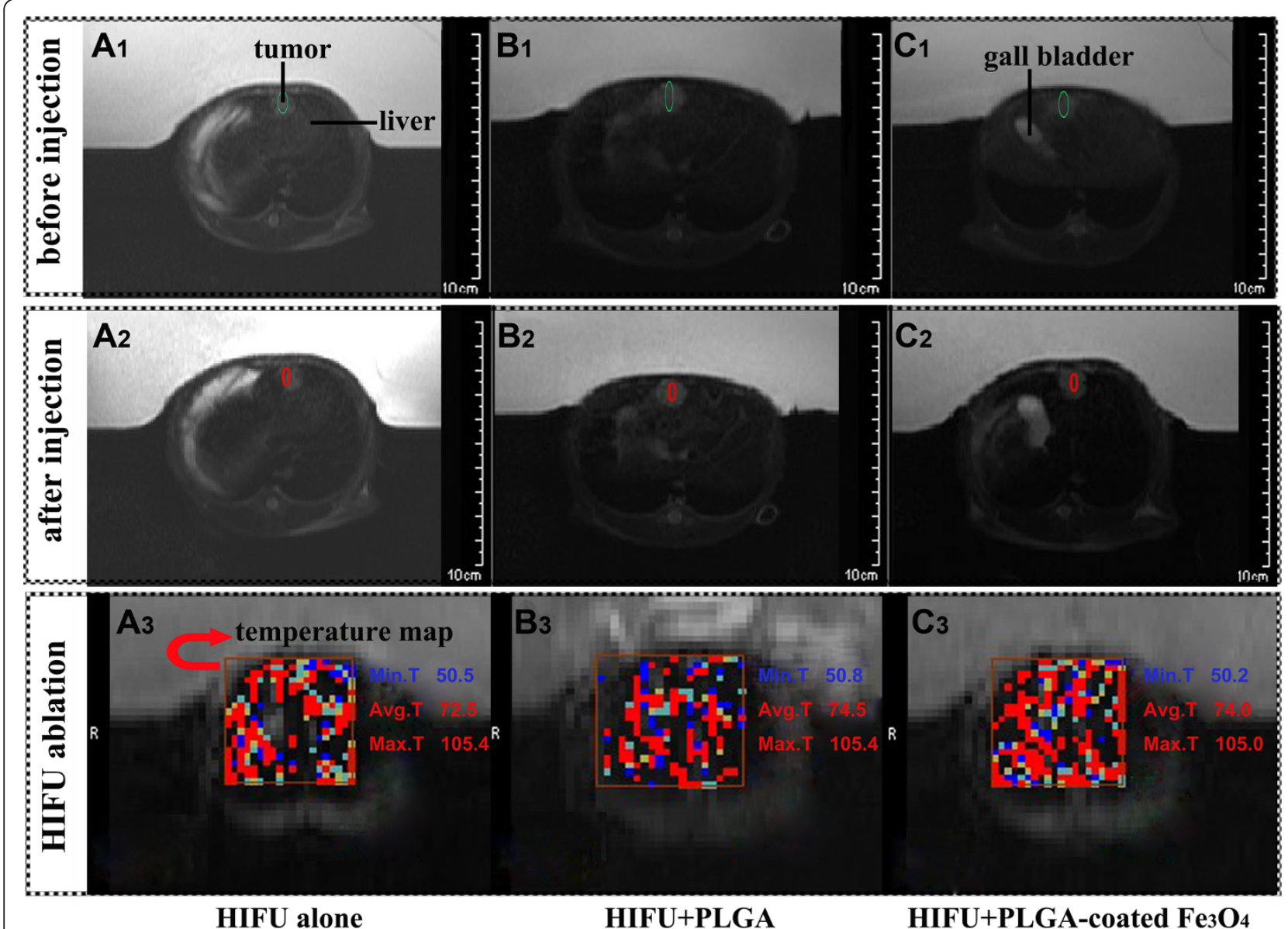

Figure 5 MR-guided HIFU liver cancer surgery (six rabbits were used in each group). (A) MR-guided HIFU alone. (B) MR-guided HIFU + pure PLGA microcapsules. (C) MR-guided HIFU + PLGA-coated Fe $\mathrm{O}_{4}$ microcapsules. $\left(\mathbf{A}_{1} / \mathbf{B}_{1} / \mathbf{C}_{1}\right) \mathrm{T}_{2}$-weighted images of the targeted tissue before MR-guided HIFU ablation (the green circle indicates the tumor site). $\left(\mathbf{A}_{\mathbf{2}} / \mathbf{B}_{\mathbf{2}} / \mathbf{C}_{\mathbf{2}}\right) \mathrm{T}_{2}$-weighted images of the targeted tissue at 5 min after the injection of different agents (the red circle identifies the region that HIFU was focused upon). $\left(\mathbf{A}_{\mathbf{3}}, \mathbf{B}_{\mathbf{3}}, \mathbf{C}_{\mathbf{3}}\right)$ Tissue temperature mapping during MR-guided HIFU ablation. minT, minimum temperature; avgT, average temperature; maxT, maximum temperature. 

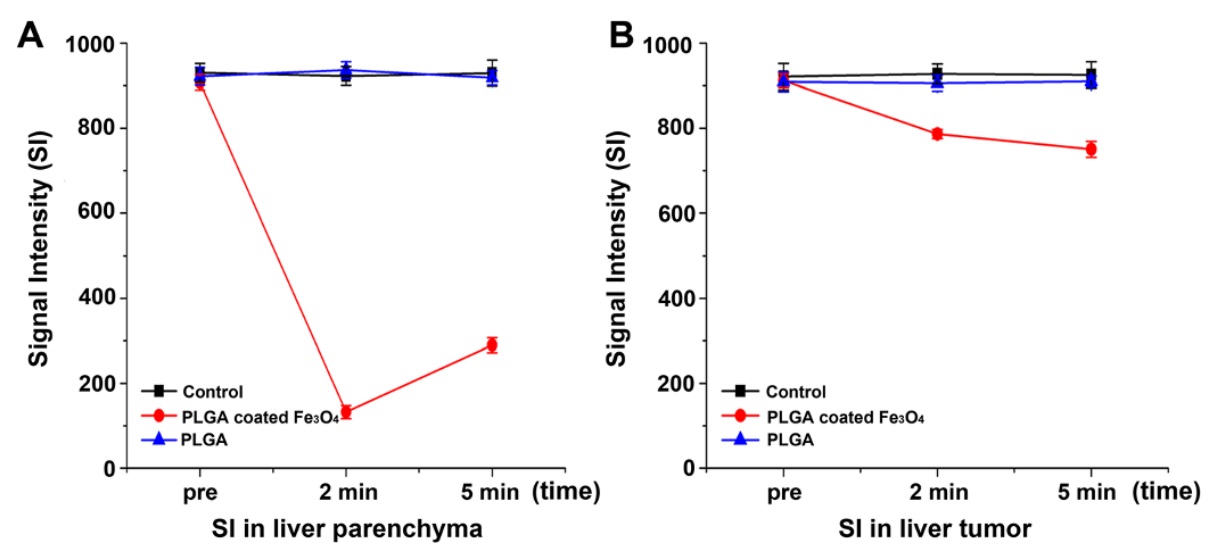

Figure 6 Analysis of MR signal intensity. The MR signal intensities from T2-weighted images of (A) normal liver parenchyma and (B) tumor before and after the injection of different agents. The error bars represent the standard deviation.

agent in either the normal liver parenchyma or the liver tumor at each time point $(P>0.05)$, the SI was significantly decreased in the normal liver parenchyma after administration of the PLGA-coated $\mathrm{Fe}_{3} \mathrm{O}_{4}$ microcapsules at 2 and 5 min relative to the other two groups $(P<0.05)$; however, the SI was decreased to a significantly lesser degree in the liver tumor tissue at 2 and $5 \mathrm{~min}$ relative to the other two groups $(P<0.05)$. These results demonstrated a significant SI-based imaging contrast between the normal liver parenchyma and tumor tissue with the use of PLGA-coated $\mathrm{Fe}_{3} \mathrm{O}_{4}$ microcapsules; this should enhance the imaging capabilities of MR during MR-guided HIFU. We hypothesize that this differential decrease in SI between the normal liver parenchyma and tumor tissue may be due to differential phagocytosis of the microcapsules by liver Kupffer cells; this is because PLGA-coated $\mathrm{Fe}_{3} \mathrm{O}_{4}$ microcapsules have the ability to distort local magnetic characteristics to yield a negative enhancement image. This SI-based effect is beneficial for MR-guided HIFU cancer surgery, because higher-contrast MR images facilitate the accurate localization of ultrasonic energy at the desired tumor site, resulting in improved therapeutic efficiency while substantially limiting damage to the surrounding normal tissue. Therefore, administration of the PLGAcoated $\mathrm{Fe}_{3} \mathrm{O}_{4}$ microcapsules could be used to localize the tumor using the variation in MR contrast between different tissues.

PLGA-coated $\mathrm{Fe}_{3} \mathrm{O}_{4}$ microcapsules show synergy with MRguided HIFU surgery

We also investigated the properties of PLGA-coated $\mathrm{Fe}_{3} \mathrm{O}_{4}$ microcapsules as synergistic agents for MRguided HIFU liver cancer surgery. Dibaji et al. assessed the utility of using magnetic nanoparticles to enhance heating during HIFU procedures in vitro; their findings demonstrated that the introduction of magnetic
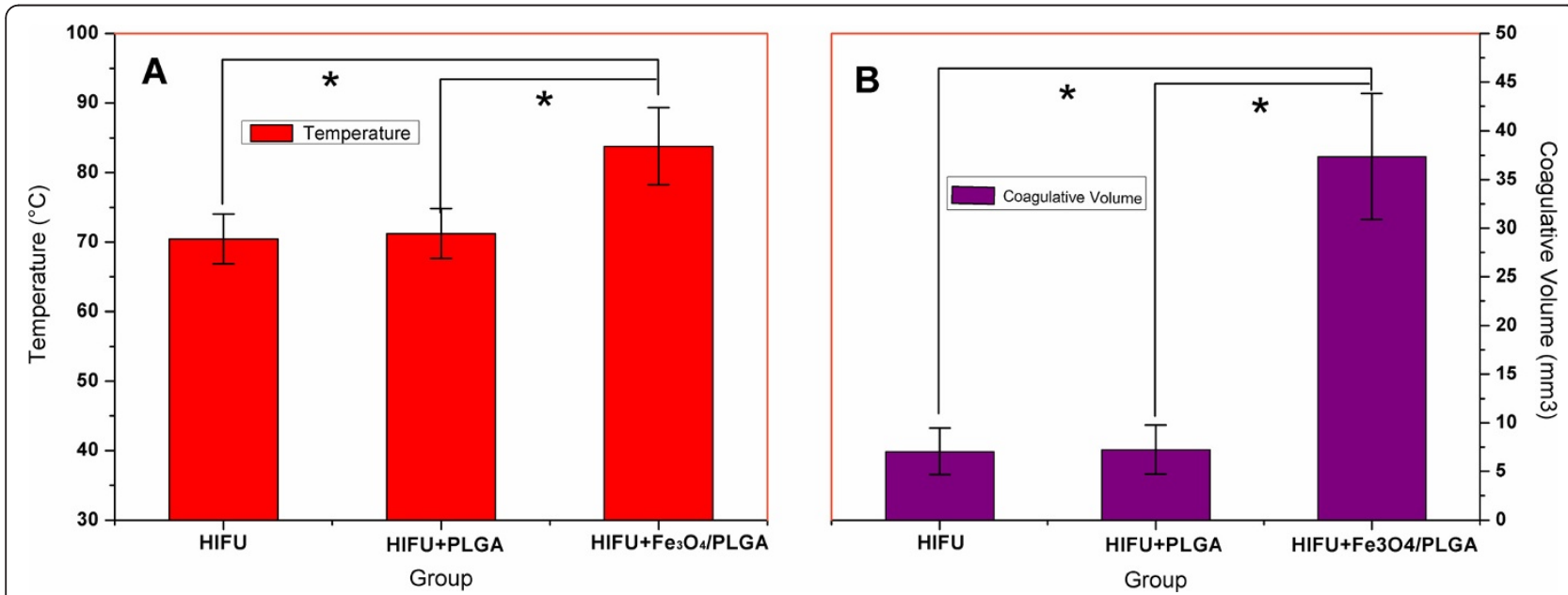

Figure 7 Tissue temperature and coagulative volume analysis. (A) Tissue temperatures of the different groups after MR-guided HIFU ablation. (B) Volume of coagulative necrosis in the different groups exposed to MR-guided HIFU. ${ }^{*} P<0.05$. 


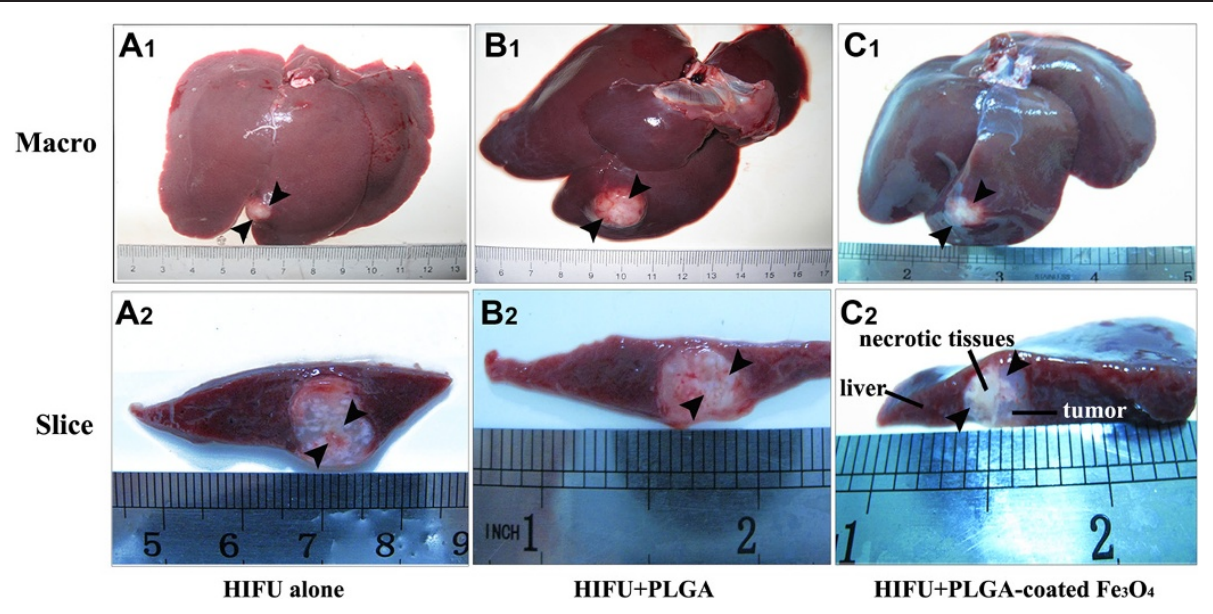

Figure 8 Macroscopic inspection of liver tumors after MR-guided HIFU. $\left(\mathbf{A}_{1} / \mathbf{A}_{2}\right)$ MR-guided HIFU alone. $\left(\mathbf{B}_{1} / \mathbf{B}_{2}\right) \mathrm{MR}-$ guided HIFU + pure PLGA microcapsules. $\left(\mathbf{C}_{1} / \mathbf{C}_{2}\right)$ MR-guided HIFU + PLGA-coated $\mathrm{Fe}_{3} \mathrm{O}_{4}$ microcapsules. Black arrows indicate the necrotic tissue in the liver tumors.

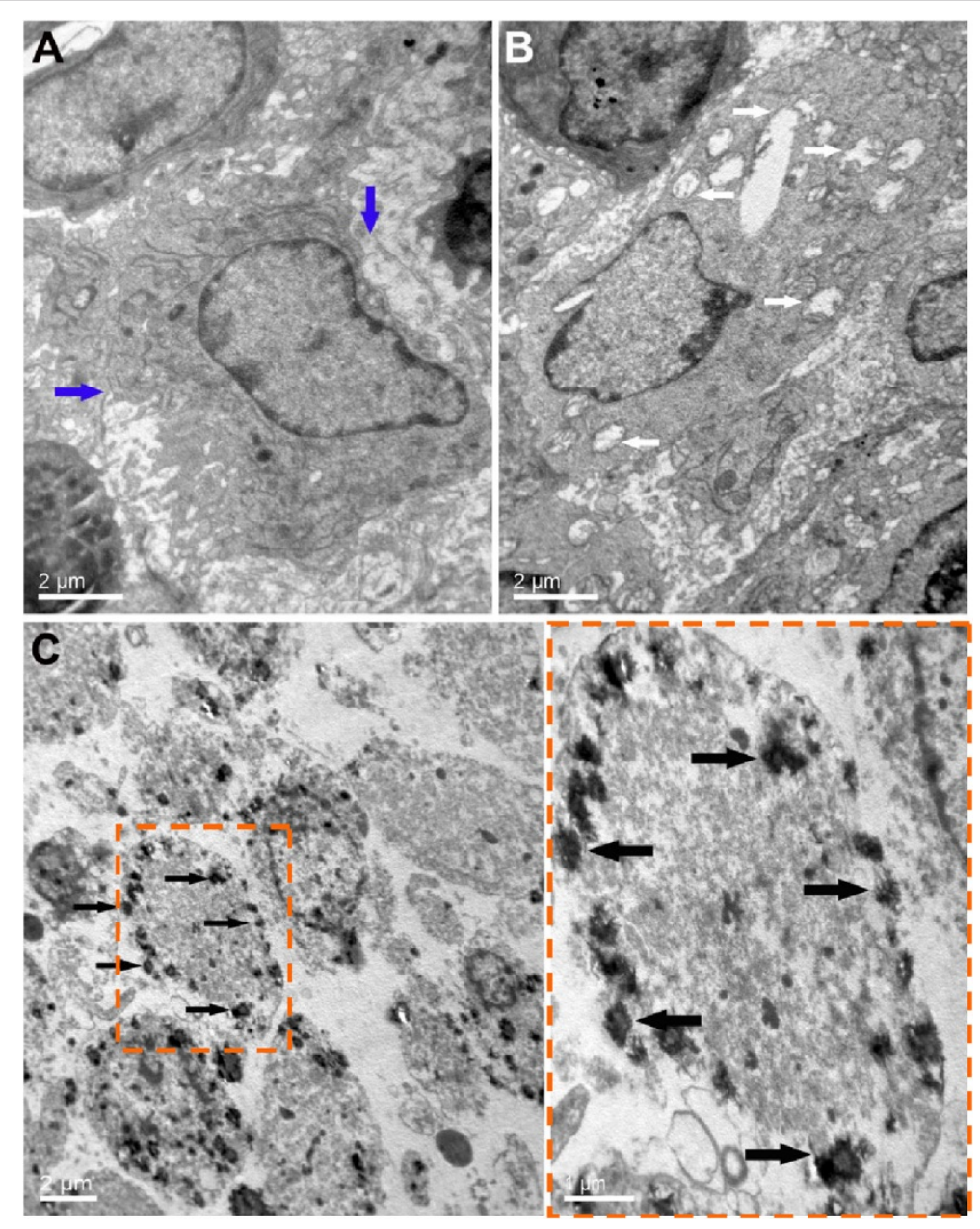

Figure 9 Transmission electron microscope images of ablated tumor tissue. (A) MR-guided HIFU alone. The blue arrows indicate the interrupted cell membranes. (B) MR-guided HIFU + pure PLGA microcapsules. The white arrows indicate the distended mitochondria. (C) MR-guided $\mathrm{HIFU}+\mathrm{PLGA}$-coated $\mathrm{Fe}_{3} \mathrm{O}_{4}$ microcapsules. The black arrows indicate the superparamagnetic PLGA-coated $\mathrm{Fe}_{3} \mathrm{O}_{4}$ microcapsules. 
nanoparticles could locally increase the temperature [36]. In the present study, PLGA-coated $\mathrm{Fe}_{3} \mathrm{O}_{4}$ microcapsules were intravenously administrated via the ear vein into rabbits with VX2 liver tumors. The microcapsules penetrated the liver tumor tissue as a result of the EPR effect and enhanced MR-guided HIFU ablation.

During MR-guided HIFU ablation, T-Map provided precise, real-time evaluation of the therapeutic effect. As shown in Figure $5 A_{3}, B_{3}$ and $C_{3}$, T-Map provided data on the extent of thermal ablation in the targeted tissue during treatment. Reliable thermal feedback from T-Map showed that the average temperature of the targeted tissue was raised by $>70^{\circ} \mathrm{C}$, indicating that the ultrasonic probe successfully focused a high-energy beam on the tumor tissue, resulting in the induction of coagulative necrosis. In addition, the average temperature of the ablated region was significantly higher in the MR-guided HIFU group using the PLGA-coated $\mathrm{Fe}_{3} \mathrm{O}_{4}$ microcapsules compared with the MR-guided HIFU group using pure PLGA microcapsules, or the MR-guided HIFU group without microcapsules (Figure 7A; $P<0.05$ ). Moreover, the volume of coagulative necrosis was substantially larger in the MRguided HIFU group with PLGA-coated $\mathrm{Fe}_{3} \mathrm{O}_{4}$ microcapsules relative to either the MR-guided HIFU group with pure PLGA microcapsules or the MR-guided HIFU group without microcapsules $(P<0.05$; Figures $7 \mathrm{~B}$ and 8$)$. Six TEM images were compared in each group for investigation of the ultramicrostructure of the targeted tumor tissue after MR-guided HIFU ablation. The results (Figure 9) regarding tumor tissue indicated that: (i) MR-guided HIFU ablation was evident; (ii) ultrastructural changes were apparent; (iii) mitochondria were severely distended; and (iv) cell membranes and nuclear membranes were interrupted and undefined. In the MR-guided HIFU group with PLGA-coated $\mathrm{Fe}_{3} \mathrm{O}_{4}$ microcapsules, the microcapsules were deposited in the tumor cells, further demonstrating that they had entered the targeted tumor tissue.

\section{Conclusions}

PLGA-coated $\mathrm{Fe}_{3} \mathrm{O}_{4}$ microcapsules combine the merits of the unique magnetic properties of SPIONs and the excellent biocompatibility of PLGA particles that make them attractive biomaterial candidates for MR-guided HIFU cancer ablation. These paramagnetic microcapsules exhibited contrast-enhanced imaging capability regarding MR imaging after intravenous injection; they effectively improved the accuracy of MR-guided HIFU liver cancer surgery. In addition, the introduction of PLGA-coated $\mathrm{Fe}_{3} \mathrm{O}_{4}$ microcapsules enhanced ultrasonic wave absorption and energy deposition in the targeted tissue, boosting hyperthermia in the targeted tissue and improving thermal ablation using MR-guided HIFU in the focused region. Furthermore, the PLGA-coated $\mathrm{Fe}_{3} \mathrm{O}_{4}$ microcapsules exhibited an excellent acute biosafety profile both in vitro and in vivo. However, the size of the superparamagnetic microcapsules used in the current study was slightly larger than those previously used. This was a limitation of our study and should be addressed in future investigations. In short, the administration of PLGA-coated $\mathrm{Fe}_{3} \mathrm{O}_{4}$ microcapsules provides an alternative strategy for MR-guided non-invasive HIFU synergistic therapy of cancer.

\section{Additional file}

\section{Additional file 1: Size distribution of the PLGA-coated $\mathrm{Fe}_{3} \mathrm{O}_{4}$} microcapsules.

\section{Competing interests}

The authors declare that they have no competing interests.

\section{Authors' contributions}

YS prepared the composite microcapsules, performed the animal experiments and drafted the paper. YYZ participated in the design of the study and helped to revise the paper. PL evaluated the characteristics of the microcapsules, DW participated in the MRI-guided HIFU therapy, CCN helped to carry out the cell experiments, YPG participated in the assessment of the biosafety of the microcapsules, and RZH contributed to the MTT assay of cell viability and revision of the manuscript. ZBW helped to carry out the MRI-guided HIFU liver surgery. ZGW participated in the design of the study, and in its analysis. HTR designed the study, participated in the data analysis and helped to revise the paper. All authors read and approved the final manuscript.

\section{Acknowledgments}

This work was partly supported by the National Nature Science of China (Grant Numbers 81471713, 81371579, 81401423 and 81161120548), the National Research Program of China (973 Program, Grant Number 2011CB707905) and Chongqing University Innovation Team Plans (KJTD201303). The authors are grateful to Yang Zhou, Ph.D., and Hongxia Shen for their assistance with the animal experiments. We also thank Wei Wu, Yingjiang Liu, Qi Wang and Chongyan Li for their support and technical expertise.

\section{Author details}

'Second Affiliated Hospital, Institute of Ultrasound Imaging, Chongqing Medical University, Chongqing, P. R. China. ${ }^{2}$ College of Biomedical Engineering, Chongqing Medical University, Chongqing, P. R. China.

Received: 11 April 2014 Accepted: 24 October 2014

Published: 3 November 2014

\section{References}

1. Santoro RR, Sommersguter GF: Actual state of ultrasonic therapy. Prensa Med Argent 1950, 37:2855-2864.

2. Vaezy S, Andrew M, Kaczkowski P, Crum L: Image-guided acoustic therapy. Annu Rev Biomed Eng 2001, 3:375-390.

3. Sibille A, Prat F, Chapelon JY, Abou el Fadil F, Henry L, Theillere Y, Ponchon T, Cathignol D: Extracorporeal ablation of liver tissue by high-intensity focused ultrasound. Oncology 1993, 50:375-379.

4. Illing RO, Kennedy JE, Wu F, ter Haar GR, Protheroe AS, Friend PJ, Gleeson FV, Cranston DW, Phillips RR, Middleton MR: The safety and feasibility of extracorporeal high-intensity focused ultrasound (HIFU) for the treatment of liver and kidney tumours in a Western population. Br J Cancer 2005, 93:890-895.

5. Hwang JH, Crum LA: Current status of clinical high-intensity focused ultrasound. Conf Proc IEEE Eng Med Biol Soc 2009, 2009:130-133.

6. Muto S, Yoshii T, Saito K, Kamiyama Y, Ide H, Horie S: Focal therapy with high-intensity-focused ultrasound in the treatment of localized prostate cancer. Jpn J Clin Oncol 2008, 38:192-199. 
7. Wu F, Wang ZB, Chen WZ, Zhu H, Bai J, Zou JZ, Li KQ, Jin CB, Xie FL, Su HB: Extracorporeal high intensity focused ultrasound ablation in the treatment of patients with large hepatocellular carcinoma. Ann Surg Oncol 2004, 11:1061-1069.

8. Quesson B, Laurent C, Maclair G, de Senneville BD, Mougenot C, Ries M, Carteret T, Rullier A, Moonen CT: Real-time volumetric MRI thermometry of focused ultrasound ablation in vivo: a feasibility study in pig liver and kidney. NMR Biomed 2011, 24:145-153.

9. Cline HE, Hynynen K, Hardy CJ, Watkins RD, Schenck JF, Jolesz FA: MR temperature mapping of focused ultrasound surgery. Magn Reson Med 1994, 31:628-636

10. Hynynen K, Darkazanli A, Unger E, Schenck JF: MRI-guided noninvasive ultrasound surgery. Med Phys 1993, 20:107-115.

11. Huisman M, van den Bosch MA: MR-guided high-intensity focused ultrasound for noninvasive cancer treatment. Cancer Imaging 2011, 11:S161-S166

12. Hokland SL, Pedersen M, Salomir R, Quesson B, Stodkilde-Jorgensen H, Moonen CT: MRI-guided focused ultrasound: methodology and applications. IEEE Trans Med Imaging 2006, 25:723-731.

13. Jolesz FA, Hynynen K, McDannold N, Freundlich D, Kopelman D: Noninvasive thermal ablation of hepatocellular carcinoma by using magnetic resonance imaging-guided focused ultrasound. Gastroenterology 2004, 127:S242-S247.

14. Gianfelice D, Khiat A, Amara M, Belblidia A, Boulanger Y: MR imaging-guided focused US ablation of breast cancer: histopathologic assessment of effectiveness- initial experience. Radiology 2003, 227:849-855.

15. Hesley GK, Gorny KR, Henrichsen TL, Woodrum DA, Brown DL: A clinical review of focused ultrasound ablation with magnetic resonance guidance: an option for treating uterine fibroids. Ultrasound Q 2008, 24:131-139.

16. Hindley J, Gedroyc WM, Regan L, Stewart E, Tempany C, Hynyen K, McDannold N, Inbar Y, Itzchak Y, Rabinovici J, Kim HS, Geschwind JF, Hesley G, Gostout B, Ehrenstein T, Hengst S, Sklair-Levy M, Shushan A, Jolesz F: MRI guidance of focused ultrasound therapy of uterine fibroids: early results. AJR Am J Roentgenol 2004, 183:1713-1719.

17. Cline HE, Hynynen K, Watkins RD, Adams WJ, Schenck JF, Ettinger RH, Freund WR, Vetro JP, Jolesz FA: Focused US system for MR imaging-guided tumor ablation. Radiology 1995, 194:731-737.

18. Kennedy JE: High-intensity focused ultrasound in the treatment of solid tumours. Nat Rev Cancer 2005, 5:321-327.

19. Lynn JG, Zwemer RL, Chick AJ: The biological application of focused ultrasonic waves. Science 1942, 96:119-120

20. Tempany CM, McDannold NJ, Hynynen K, Jolesz FA: Focused ultrasound surgery in oncology: overview and principles. Radiology 2011, 259:39-56.

21. Harari PM, Hynynen KH, Roemer RB, Anhalt DP, Shimm DS, Stea B, Cassady JR: Development of scanned focussed ultrasound hyperthermia: clinical response evaluation. Int J Radiat Oncol Biol Phys 1991, 21:831-840.

22. Mahmoudi M, Serpooshan V, Laurent S: Engineered nanoparticles for biomolecular imaging. Nanoscale 2011, 3:3007-3026

23. Dong W, Li Y, Niu D, Ma Z, Gu J, Chen Y, Zhao W, Liu X, Liu C, Shi J: Facile synthesis of monodisperse superparamagnetic Fe304 Core@hybrid@Au shell nanocomposite for bimodal imaging and photothermal therapy. Adv Mater 2011, 23:5392-5397.

24. Laurent S, Bridot JL, Elst LV, Muller RN: Magnetic iron oxide nanoparticles for biomedical applications. Future Med Chem 2010, 2:427-449.

25. Lee JH, Schneider B, Jordan EK, Liu W, Frank JA: Synthesis of complexable fluorescent superparamagnetic iron oxide nanoparticles (FL SPIONs) and cell labeling for clinical application. Adv Mater 2008, 20:2512-2516.

26. Frascione D, Diwoky C, Almer G, Opriessnig P, Vonach C, Gradauer K, Leitinger G, Mangge $H$, Stollberger R, Prassl R: Ultrasmall superparamagnetic iron oxide (USPIO)-based liposomes as magnetic resonance imaging probes. Int J Nanomedicine 2012, 7:2349-2359.

27. Bulte JW, Hoekstra Y, Kamman RL, Magin RL, Webb AG, Briggs RW, Go KG, Hulstaert CE, Miltenyi S, The TH: Specific MR imaging of human lymphocytes by monoclonal antibody-guided dextran-magnetite particles. Magn Reson Med 1992, 25:148-157.

28. Guo RM, Cao N, Zhang F, Wang YR, Wen XH, Shen J, Shuai XT: Controllable labelling of stem cells with a novel superparamagnetic iron oxide-loaded cationic nanovesicle for MR imaging. Eur Radio/ 2012, 22:2328-2337.

29. Tong L, Zhao M, Zhu S, Chen J: Synthesis and application of superparamagnetic iron oxide nanoparticles in targeted therapy and imaging of cancer. Front Med 2011, 5:379-387.
30. Alexiou C, Arnold W, Klein RJ, Parak FG, Hulin P, Bergemann C, Erhardt W, Wagenpfeil S, Lubbe AS: Locoregional cancer treatment with magnetic drug targeting. Cancer Res 2000, 60:6641-6648.

31. Luo W, Zhou X, Yu M, He G, Zheng X, Li Q, Liu Q, Han Z, Zhang J, Qian Y: Ablation of high-intensity focused ultrasound assisted with Sonovue on rabbit VX2 liver tumors: sequential findings with histopathology, immunohistochemistry, and enzyme histochemistry. Ann Surg Oncol 2009, 16:2359-2368.

32. Yu T, Wang G, Hu K, Ma P, Bai J, Wang Z: A microbubble agent improves the therapeutic efficiency of high intensity focused ultrasound: a rabbit kidney study. Urol Res 2004, 32:14-19.

33. Rapoport N, Nam KH, Gupta R, Gao Z, Mohan P, Payne A, Todd N, Liu X, Kim T, Shea J, Scaife C, Parker DL, Jeong EK, Kennedy AM: Ultrasoundmediated tumor imaging and nanotherapy using drug loaded, block copolymer stabilized perfluorocarbon nanoemulsions. J Control Release 2011, 153:4-15.

34. Hobbs SK, Monsky WL, Yuan F, Roberts WG, Griffith L, Torchilin VP, Jain RK: Regulation of transport pathways in tumor vessels: role of tumor type and microenvironment. Proc Natl Acad Sci 1998, 8:4607-4612.

35. Campbell RB: Tumor physiology and delivery of nanopharmaceuticals. Anticancer Agents Med Chem 2006, 6:503-512.

36. Dibaji SAR, Al-Rjoub MF, Myers MR, Banerjee RK: Enhanced heat transfer and thermal dose using magnetic nanoparticles during HIFU thermal ablation-an in-vitro study. J Nanotechnol Eng Med 2014, 4(041003):1-8.

doi:10.1186/1471-2407-14-800

Cite this article as: Sun et al:: Evaluation of superparamagnetic iron oxide-polymer composite microcapsules for magnetic resonance-guided high-intensity focused ultrasound cancer surgery. BMC Cancer $201414: 800$.

\section{Submit your next manuscript to BioMed Central and take full advantage of:}

- Convenient online submission

- Thorough peer review

- No space constraints or color figure charges

- Immediate publication on acceptance

- Inclusion in PubMed, CAS, Scopus and Google Scholar

- Research which is freely available for redistribution 